\title{
Pleural Mesothelioma pT3 TNM Finding v7
}

National Cancer Institute

\section{Source}

National Cancer Institute. Pleural Mesothelioma pT3 TNM Finding v7. NCI Thesaurus.

Code C88904.

Pleural mesothelioma with a locally advanced but potentially respectable tumor. Tumor involving all the ipsilateral pleural surfaces (parietal, mediastinal, diaphragmatic, and visceral pleura) with at least one of the following: involvement of the endothoracic fascia; extension into the mediastinal fat; solitary, completely respectable focus of tumor extending into the soft tissues of the chest wall; nontransmural involvement of the pericardium. (from AJCC 7th Ed.) 